\title{
Recommendations for a New Portuguese Teacher Placement System
}

\author{
Danilo Santos $^{1}$, Jorge Oliveira ${ }^{1,2}$ e Sá, Luís Paulo Reis ${ }^{1,2,3}$, Brigida Mónica \\ Faria $^{3,4,5}$ \\ ${ }^{1}$ DSI/EEUM - Departamento de Sistemas de Informação, Escola de Engenharia da \\ Universidade do Minho, Guimarães, Portugal \\ ${ }^{2}$ Centro ALGORITMI, Universidade do Minho, Guimarães, Portugal \\ ${ }^{3}$ LIACC - Laboratório de Inteligência Artificial e Ciência de Computadores, Porto, \\ Portugal \\ ${ }^{4}$ ESTSP/IPP - Escola Superior de Tecnologia da Saúde do Porto, Instituto Politécnico do \\ Porto, Gaia, Portugal \\ ${ }^{5}$ INESC-TEC - Instituto de Engenharia de Sistemas e Computadores, Tecnologia e \\ Ciência, Porto, Portugal \\ danilo92@sapo.pt, \{jos,lpreis\}dsi.uminho.pt, btf@estsp.ipp.pt
}

\begin{abstract}
Portuguese teacher placements' system is a centralized system managed by the Portuguese government, specifically by the Ministry of Education and Science. It is a system with some issues and, therefore, has been criticized by its stakeholders, mainly by teachers. This paper aims to do a systematic review and a meta-analysis of the Portuguese teacher placements' system. An objective is to understand and describe how this system works in European Union countries. Another objective is to interview school specialists, in this particular case - teachers, to find solutions for teacher placements' system. Finally, from solutions from European Union countries and from solutions arising from schools' specialists, a set of requirements is identified that the teacher placements' system should take into account, in order to avoid the issues identified.
\end{abstract}

Keywords: High School; Teaching System; Teacher Placement.

\section{Introduction}

Whenever a new school year begins in Portugal, the teacher placement system has been criticized because the occurrence of problems, namely: the fact of teachers are placed far from their residential area; the criteria that determine the ranking of teachers for subsequent placement in a school are not fully understood and, possibly, are wrong; and the number of school jobs vacancies is not according of the needs of each school, forcing schools to open additional job vacancies [1].

This impacts and causes disorder to teachers at several levels: at professional level, because, if teachers don't get a job vacancy or teachers only get a part-time job vacancy, this may cause absence or reduction of monthly remuneration; at personal 
level, because it forces the teachers, in most cases, to change their local of residence, sometimes very far from home and friends, causing, every year, the teachers have to start a new life from scratch; and at family level, because, sometimes, this cause a separation from teachers' family (husband's/spouse's and children's).

This system also impacts on students, because if a school job vacancy are not filled on time, may causes a (long) time without classes to a particular discipline, which jeopardize students learning and respective school success.

We emphasizes that the teacher placement system affects thousands of teacher candidates to school vacancies and many of them are not placed in a school when many schools are left with unfilled vacancies.

Therefore, it is pertinent to describe the process of teachers' placement in Portugal, i.e., what are the criteria used for teachers' placement in a particular school, understand the failures, and thus, improve the process of teachers' placement system.

Portugal is part of the European Union, so it is important to compare the teachers' placement system in Portugal with other European countries and describe the differences between these countries.

This study must take into account who knows the education system, i.e. teachers. The main goal is to collect and realize the teachers' opinion about the system that is in place in Portugal and understand they agreement, or not, about replace the existing system by implementing a new system.

This paper presents the following objectives:

- describe the process at national level;

- describe the process at other European countries;

- identify proposals for improvements;

- conduct a survey to collect and realize the teachers' opinion about the current process of teachers' placement system; and

- analyze the questionnaires.

The paper is organized as follows: Section 2 presents the teacher placement system in Portugal and other European countries. It also presents a comparison between the existing system in Portugal and other European countries; Section 3 describes three proposals to improve the Portuguese teachers' placement system; Section 4 presents the results obtained from the questionnaire done; Section 5 provides a list of recommendations / requirements need to be incorporated into a new teachers' placement system; and finally, conclusions are presented.

\section{Teachers Placement System in Portugal}

The current system for place teachers in schools vacancies in Portugal is divided into two parts: the internal placement system; and the external placement system [2]. 


\subsection{Internal Placement System}

To start the process, a teacher select a Pedagogical Zone Board (PZB), a PZB is a defined territorial region of Portugal, in Figure 1 shows ten Portugal PZB's [3], [4], [5]. After that, a teacher can apply for a certain number of schools by choosing the preference school, i.e., in descending order the teacher refers schools where prefer to work [5].

If a teacher is placed in a school, it is important to remark, in the next year he/she can change the school by moving to another school with vacancies on the school board, the teacher can do this by Internal Mobility system [6].

A teacher to apply to internal placement system have to fill in various forms and follow some steps. The application is made as follows: first, the teacher fill in forms about personal and professional information. Then, the teacher must select the PZB which intends to teach and the number of recruitment group to which the teacher are applying. Finally, the teacher fill in the form about their school graduation and define the school priority ranking where intends teaching.

Is described below in more detail the application process: a teacher to be eligible to internal mobility have to apply through a web application and have to fill in a set of electronic forms [6]. Firstly, the teacher selects the menu concerning the internal mobility, which fill in a form with personal information, and provide the reason why he/she are applying to internal mobility. If the teacher wants to change to one school, but remain at the same PZB, the teacher must select the "Framework group of schools / ungrouped schools board" option. If the teacher plans to change to other PZB, he/she must select the "Framework educational zone" option. Finally, the teacher have to fill in the form about he/she employment status, by indicating the type of school by filling the respective codes and the teacher need to inform the reason why he/she apply to internal mobility, i.e., why he/she wants to change to other schools or other PZB.

After the teacher apply to a PZB or to a school, the teacher placement is independent of the PZB of he/she belongs, i.e., if a teacher wants to apply for an existing school vacancy, from the same PZB or different PZB, he/she can do it if there are school board vacancies, or if there a teacher at this school in the same situation [6]. Here is an example: if a teacher wants to change from one city schools to another different city school, for any reason, he/she can do it by providing if there are vacancies at the school where he/she wants to go.

It is important to remark, this process occurs every years.

\subsection{External Placement System}

Teachers can apply to three different types of schools [4]:

- schools with autonomy agreement, these schools have autonomy to hire teachers. These are usually schools with students with special features, such art schools, music schools, ... [3] [7]; 
- special schools are schools dealing with students from different ethnic groups with disadvantaged social classes, with affected households and who are in degraded areas [3] [8]; and

- normal schools [3].

Within the external placement system, teachers firstly apply to normal schools by defining a priority ranking from 1 to 100 .

Teachers who have not been placed in a school vacancy, transit to a Recruitment List, the teacher in the application form can choose if he/she wants to enter in this Recruitment List [9]. The Recruitment List aims to identify teachers available, if necessary, to replace teachers that became unable to teach.

With regard to schools with autonomy agreement and special schools [10], teachers who have not been placed transit to a School Recruitment List [5].

In the Recruitment List teachers are ordered using the formula (1) [4] [18]:

$$
P C(\text { final course grade })+D P(\text { experience })
$$

Where $P C$ corresponds to the Professional Classification (final course grade between 10 to 20 points) and $D P$ corresponds to Degree Professional (for every 365 working days is assigned 1 point).

In School Recruitment List teachers are ordered using the following formula (2).

$P C$ (final course grade) + Test_Curriculum (questions to teachers)

Where $P C$ corresponds to the Professional Classification (final course grade between 10 to 20 points) and Test_Curriculum (schools evaluate teachers through a set of questions and at the end the teacher is evaluated by a grade between 0 to 200 points). 

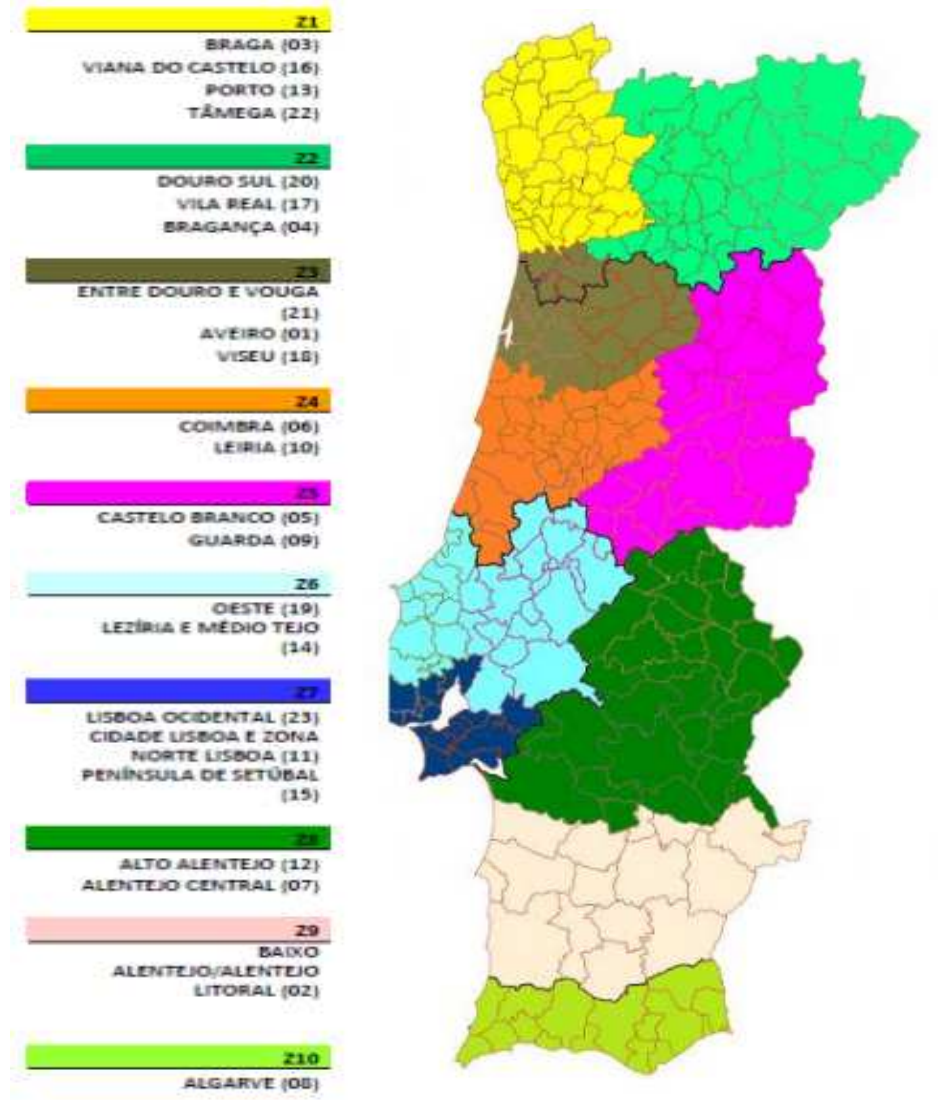

Fig. 1. Country division into ten PZB's.

Teachers needs to fill in an electronic form to apply to external placement [9]. The application process starts, when the teacher choose the menu "Professional situation", then he/she need to choose the submenu "External Extraordinary Contest" or "Initial Hiring and Recruitment Reserve", after that the teacher fill in a form with personal and professional information, then the teacher have to choose the school vacancy he/she wants by selecting the type of school code (with autonomy contract, special or normal schools) and the PZB correspondent. Finally, the teacher indicates the Professional Classification, to do this he/she inserts the recruitment code by fill in an electronic form with information with the number of days of experience (paid teaching service). 


\subsection{System placement in other European Countries}

Portuguese teacher placement system is so criticized by all entities that interact with it because of errors and issues pointed to the system [1] [11], we decided to considerer other systems from European countries.

So, we performed a brief description of the process of schools vacancies placement / recruitment of teachers in European countries, namely UK (Scotland), Netherlands, Spain, Italy, France and Germany, namely:

- UK / Scotland - the Scottish Government together with the General Teaching Council for Scotland, local authorities, teachers' unions and universities manage the teacher placement process. The method used for the school vacancies placement of teachers, undergoes a process of raising some relevant information such as: the number of existing students; the number of teachers needed; the number of teachers leaving the profession; and the number of teachers entering the profession in the next school year. The system calculates the number of teachers needed to fill the gap between supply and demand. With this, the method permits to hire a precise and exact number of teachers to fill the needs [12].

- Netherlands - the placement of teachers is done through an open recruitment, i.e., the responsibility for disclosure of vacancies available for teachers to apply is the responsibility of the schools, sometimes acting in conjunction with local authorities. The schools decide and implement the procedures and methods for teachers' recruitment. Thus, the process for school vacancy placing teachers is a decentralized process, because who decides to hire teachers are schools [13].

- Spain - the teacher recruitment method is done through an examination, i.e., if a teacher wants to teach in a public school, he/she must subject to an exam and obtain a positive classification. The exam is divided into three phases: the first phase is to evaluate the specific knowledge to the field or specialty, aptitude for learning and mastery of spoken necessary teaching techniques, that is, a phase introduction, a theoretical phase; the second phase aims to evaluate the training and experience of each teacher, this is basically what is assessed at this stage, is the curriculum of each teacher; and the third and final phase consists of a more practical component because teachers are subject to a probationary period where they have to demonstrate their qualities as teachers. This phase may be the most important phase of the three because the teacher demonstrate the ability to teach [13].

- Italy - the recruitment method used in Italy is through an examination, such as in Spain [13]. The teachers are divided in regions (provinces) and the exam enable to sort teachers by exam classification in each region. Some important points to remember are: the examination is based only on disciplinary assessment and not on the actual candidates' capabilities; the examination committee is not composed of any range of specialists and experts in the area, this committee consists of teachers who are not selected or prepared for the exam; commissions have not set out any criteria or evaluation methods, this can cause, for example, that all teachers are passed 
or possibly all fail [14]. According to Italian legislation, the exam is intended only to form a list of qualified candidates at regional level. In fact, a teacher already contracted is under the Regional School Office, this office belong to the Italian Ministry of Education. On the other hand, teachers without a contract, or temporary contracted, are recruited from a regional list and the contract is made directly with the school [13].

- France - the method used in France is similar to the method followed in Spain and Italy, i.e., there is an exam [12]. This exam is made available by the Ministry of Education [15]. Firstly, teachers must have a university grade or equivalent degree to be submitted to exam [15]. After this requirement, teachers are submitted to an exam. If the teachers are approved, they spent a year training at Institut Universitaire de Formation des Maîtres (IUFM), with the label of paid trainee teachers. Finally, if teachers are approved at trainee, a school to work is attributed.

- Germany - teachers are recruited as in Portugal, i.e., through a list of candidates and the decision of school vacancies placement is from German State responsibility, although in some Länder (states), when are not enough candidates to fill the existing vacancies, local authorities have influence on recruitment [16] [17]. The candidates list is sorted by academic performance, i.e., the final classification of the university graduation. The system in German may have some school vacancies placement delays due to candidate's geographical preferences. The teachers' preferences are taken into account by authorities, which leads to teachers' greater satisfaction [17].

Comparing and analyzing the placement systems from various countries there was a certain balance in terms of systems centralization and decentralization, see Table 1. In Portugal this aspect is referred as an issue of teacher's placement system.

Tab. 2. The table shows the comparison of placement systems in some European countries

\begin{tabular}{|l|c|c|}
\hline & Centered & Decentralized \\
\hline Portugal & $\mathrm{X}$ & \\
\hline UK/ Scotland & & $\mathrm{X}$ \\
\hline Netherlands & & $\mathrm{X}$ \\
\hline Spain & $\mathrm{X}$ & \\
\hline Italy & $\mathrm{X}$ & \\
\hline France & $\mathrm{X}$ & \\
\hline Germany & $\mathrm{X}$ & $\mathrm{X}$ \\
\hline
\end{tabular}




\section{Improvement Proposals}

Due to the complexity of the subject, because it involves political issues, some proposed improvements to the teachers' placement system are not implemented or even divulgated. However, after some research, three proposals are identified, namely:

- National Association of Teachers (NAT) - NAT suggested to the Ministry of Education to decentralize the School Recruitment List. Also suggested the creation of two Recruitment Lists at national level based on Professional Classification. Finally, suggested to other schools (with autonomy agreement and special schools) the sort criteria should be as follows: $75 \%$ for Professional Classification and 25\% for other criteria [18].

- National Federation of Teachers (FENPROF) - FENPROF proposed two different improvement proposals. Firstly, proposed a qualified teachers' sort priority, the process should occurs every year, stabilization of teachers through stabilization of schools vacancies, the ranking of the candidates settle in Professional Classification, and proposed a priority to teachers that have worked at public schools in the last recent years [19]. Secondly, FENPROF proposed to open a list weekly updated with school vacancies available all school year, suggested augment the number of PZB's, and suggested that all qualified teachers can apply to a school vacancy regardless of the criteria adopted [19].

- National Union of Licensed Teachers from Polytechnic and Universities (NULTPU) - face the challenges in education in Portugal to achieve the levels of development of others European countries, NULTPU presents a work proposal to Ministry of Education to promote the teaching stability and employment by resizing the number of school vacancies and augment the number of PZB's [20].

\section{Quantitative Analysis}

To collect teachers' opinions, a survey based in a questionnaire was send to teachers in Portugal in order to identify improvements to the current process of teachers' placement system. This was distributed using the Qualtrics online platform.

Statistical tests were applied to show evidence of possible statistical differences between groups of teachers in independent regimes.

The Mann-Whitney test for two independent samples and Kruskal-Wallis test for three or more independent samples. The significance level was 0.05.

The following results are intended to firstly characterize the sample. It may be noted that $75 \%$ of respondents are female and $25 \%$ male. With regard to age, most respondents, $53 \%$, is comprised between $30-40$ years, then between $40-50$ years old is $31 \%$, with regard to age matched between 50-60 years, represents $11 \%$ of respondents, and finally, with only $5 \%$, is the youngest respondents who are between 20-30 years old. See figure 2. 


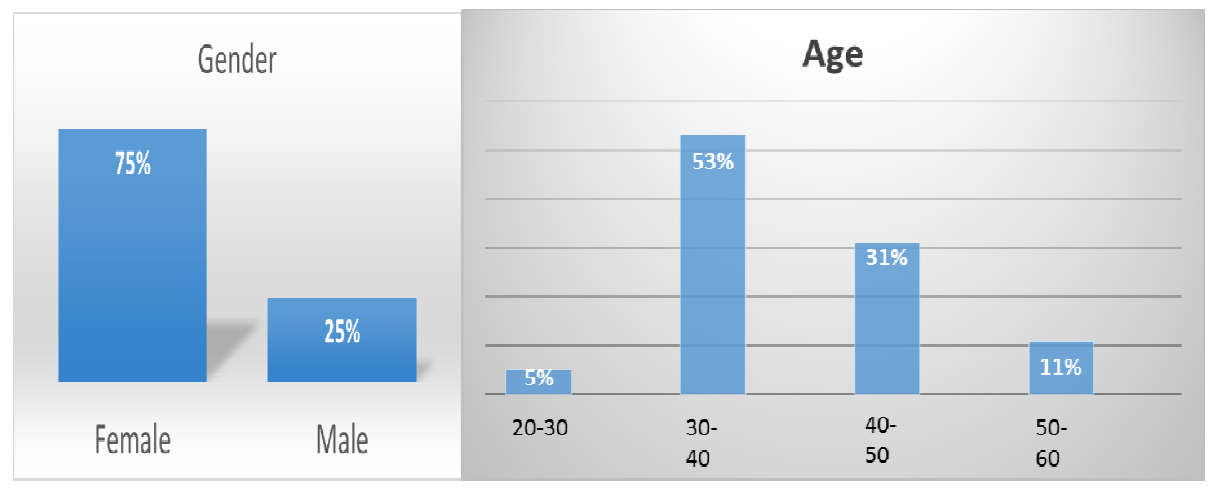

Fig. 2. Sample characteristics.

In Figure 3, in the left graph, $81 \%$ of respondents are teaching at the time of response and $19 \%$ not. Because $81 \%$ of the sample meet the teaching is an asset for this study because they have a better perception of functioning, such as problems with current teacher's placement system. In the right chart, is represented type of school that $81 \%$ of respondents is teaching, the majority, $55 \%$ of the sample, is found teaching a normal school (represented in blue on the graph), 26\% in a school with autonomy agreement (shown in orange in the chart), $11 \%$ in special school (TEIP) school (represented by gray in the graph) and finally $8 \%$ schools is teaching another type (private schools, vocational and education schools) (shown in yellow in the graph).

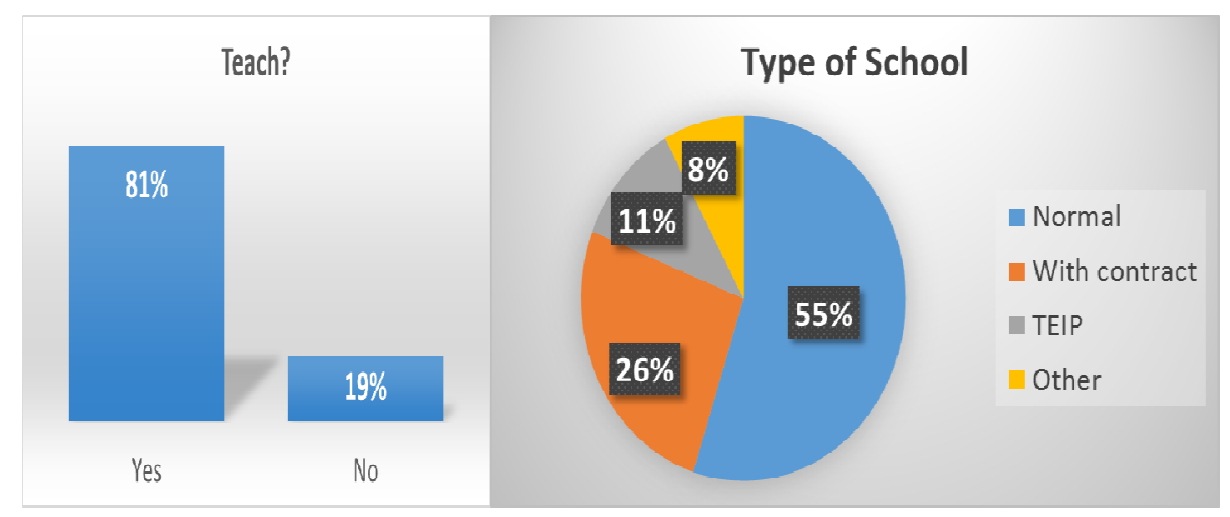

Fig. 3. Sample analysis I 
Moving on to the analysis of the Internal and External school teachers' placement system, it was asked to respondents to rate the system between "Bad", "Reasonable", "Good" or "very good", see figure 4.

The left chart represents the classification of Internal Placement System. Thus, $50 \%$ of the sample classifies the placement system as "Bad", $40 \%$ classifies it as "Reasonable", $8 \%$ rate it as "Good" and only $2 \%$ classify the system as "Very Good".

The right chart represents the classification of External Placement System. Thus, $68 \%$ of respondents rate it as "Bad", $24 \%$ classify it as "Reasonable", $7 \%$ as "Good" and only $1 \%$ as "Very Good".

We can conclude that there may be some dissatisfaction with those who interact with both systems due to the classification that they attributed to him.

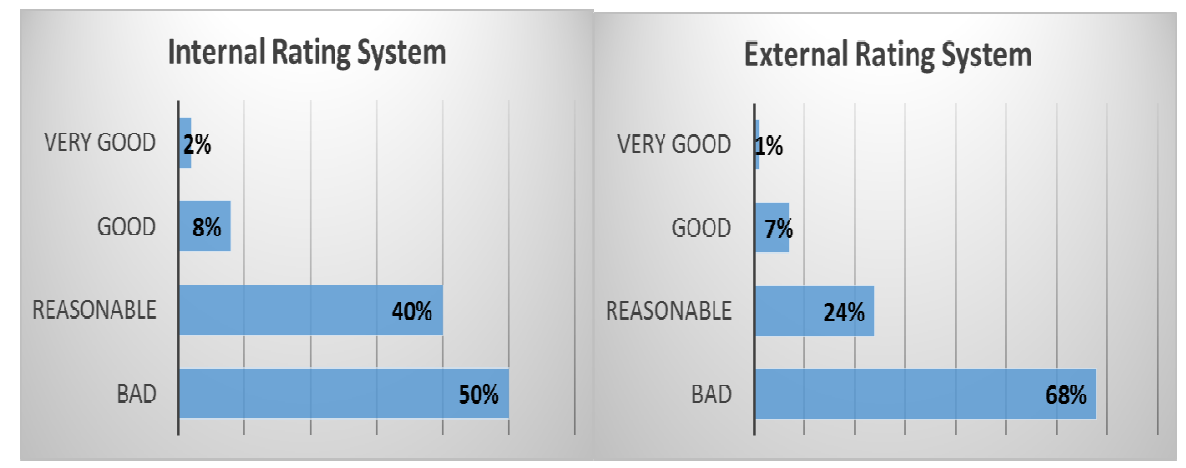

Fig. 4. Sample analysis II

The Mann-Whitney test is used to see if the classification distribution of Internal and External system by teachers' gender and those who are teaching or not are different. Regarding the type of school that teaches and age groups we used the Kruskal-Wallis test to check the differences in the distribution of the internal and external system classification.

Tab. 2. The table shows the cross-checks made after the statistical analysis.

\begin{tabular}{|r|c|c|}
\hline & \multicolumn{2}{|c|}{ Test values } \\
\cline { 2 - 3 } Gender & Internal & External \\
\hline It is to teach & 0.063 & 0.467 \\
\hline Type of school & 0.094 & 0.656 \\
\hline Age Group & $0.021^{*}$ & 0.113 \\
\hline
\end{tabular}


The results demonstrate a significant statistical evidence to assert that the classification of the internal system is considered differently by teachers working in different kind of school and for different age groups, for a significance level of 0.05 .

With regard to PZB's division implemented, the respondents' advocates increased number of PZB's, with $58 \%$ of responses, $21 \%$ of the respondents believes that the division should be done in municipalities, $8 \%$ decreased the number existing PZB's, $7 \%$ was the division following the division into regions, only $4 \%$ of the sample is satisfied with the current division and finally $2 \%$ advocated another option, such the elimination of PZB's.

We asked the respondents if they agree with some list of recruitment, $61 \%$ of the respondents not agree with any of the recruitment lists, only $27 \%$ agree only with the Recruitment List, but $7 \%$ of the respondents agree with the actual process, that is, with the two recruitment lists, finally, $5 \%$ of the respondents agree only with the School Recruitment List.

To propose a solution to please everyone, $90 \%$ of the respondents agree with the existence of only one list of recruitment and $10 \%$ disagreed with the idea.

To determine what is the best formula for sorting teachers in the recruitment list, $41 \%$ of the respondents supports the Professional Graduation as principal and fair criteria, $28 \%$ believes that the best criteria should be Professional Classification, $21 \%$ support the Professional Rating + Curriculum should be the fair formula for sorting teachers and, finally, $10 \%$ of the sample believes that the Professional Classification + Service Time should be the most effective way to sort teachers.

\section{Recommendations for a new Teacher Placement System in Portugal}

Based on problems and issues identified and solutions presented by teachers, a list of suggested recommendations / requirements to the new system has been presented. In table 3 a list of requirements for Internal and External school teachers' placement system is presented. For each requirement, we describe the "Aspect Improve" which describes the problem identified, "Change" describes the proposed solution and "Tips" where the proposed solution is detailed and explained.

Tab. 3. Requirements to improve the Teachers Placement System.

\begin{tabular}{|c|l|l|}
\hline \multicolumn{2}{|c|}{ Internal Placement System } \\
\hline $\begin{array}{c}\text { Aspect to } \\
\text { improve }\end{array}$ & Changes & Suggestions \\
\hline PZB's & $\begin{array}{l}\text { Reduce the size of } \\
\text { existing PZB's }\end{array}$ & $\begin{array}{l}\text { Some current PZBs address various districts. By } \\
\text { using the district as split area, the number of } \\
\text { PZB's increments from ten to eighteen. }\end{array}$ \\
\hline
\end{tabular}




\begin{tabular}{|c|c|c|}
\hline \multicolumn{3}{|c|}{ External Placement System } \\
\hline $\begin{array}{l}\text { Existing } \\
\text { recruitment lists }\end{array}$ & $\begin{array}{l}\text { Only use a } \\
\text { recruitment list }\end{array}$ & $\begin{array}{l}\text { All teachers will be placed by a single list and } \\
\text { will later be recruited from this list always } \\
\text { taking into account the requirements and needs } \\
\text { of each school. }\end{array}$ \\
\hline $\begin{array}{l}\text { Existing } \\
\text { formulas } \\
\text { placement }\end{array}$ & $\begin{array}{l}\text { Implement a new } \\
\text { formula }\end{array}$ & $\begin{array}{l}\text { - The Professional Graduation (GP) was the } \\
\text { main criteria, especially highlighting the } \\
\text { substantive issues. The Professional } \\
\text { Classification (CP) was the second criteria } \\
\text { mentioned. It considers that the curriculum } \\
\text { will be necessary for the criteria, that is, which } \\
\text { allows to select teachers to be able to teaching } \\
\text { students with special needs. } \\
\text { - In the GP criteria, the addition of Teacher } \\
\text { Assessment criteria, this assessment will be } \\
\text { given by the school where the teacher taught } \\
\text { in such a way to evaluate their performance } \\
\text { and professionalism. The scale is } 0-1 \text { and will } \\
\text { have a weight of } 50 \% \text { of GP, the other } 50 \% \\
\text { will be assigned to the corresponding value at } \\
\text { the time of service. } \\
\text { - One option is to assign weights to various } \\
\text { criteria. Objectively it was not possible to set } \\
\text { a weight value for each criteria, but it is } \\
\text { noticeable that the GP criteria will have the } \\
\text { greatest weight, followed by CP and then } \\
\text { Curriculum. }\end{array}$ \\
\hline $\begin{array}{l}\text { Time delay in } \\
\text { the teachers } \\
\text { placement } \\
\text { system }\end{array}$ & $\begin{array}{l}\text { Reduce the trial } \\
\text { period of one month } \\
\text { to } 10 \text { days. }\end{array}$ & $\begin{array}{l}\text { The teacher placement process is a long time } \\
\text { process. One way to reduce this time is to reduce } \\
\text { the trial period, i.e., we proposed that a teacher } \\
\text { has only } 10 \text { working days to decide if he/she } \\
\text { wants to stay at a new school. If the teacher } \\
\text { choose to stay at the new school, the teacher } \\
\text { leaves the recruiting list and free the position in } \\
\text { the list. If teacher decide to leave the new } \\
\text { school, he/she releases the job place to other } \\
\text { candidates. }\end{array}$ \\
\hline
\end{tabular}

\section{Conclusions}

This paper as the following goals and objectives:

- Describe the process of teacher's placement system in Portugal.

- Describe the methods that are used in countries of European Union such as UK (Scotland), Netherlands, Spain, France, Italy and Germany and make a comparative analysis with Portugal method of teacher's placement system. 
- Identify proposals for improving the system.

- Collect teacher's opinions about the method and process of teacher's placement system through a questionnaire.

- Analyze the data collected through the questionnaire with quantitative analysis.

- Propose a list of improvements to the teacher's placement system.

All the above objectives and goals have been achieved. The current teacher's placement system in Portugal has issues and errors, particularly because it is a closed system not taking into account some relevant factors to teachers: professional, personal and family. Most countries make use of the open recruitment for the placement of teachers. It appears that there is no great discrepancy in terms of centralization and decentralization of teacher placement system.

There are some proposals to improvements to the current teacher's placement system, but for political reasons, some are not heard or implemented.

Making use of a teacher's questionnaire with the goal to gather the teacher's opinion, some improvements to the current teacher's placement system are identified.

Finally, from all the data collected a list of recommendations / requirements were presented to be incorporated into a new teacher's placement system in Portugal.

\section{Acknowledgments}

This project was funded by Fundo Europeu de Desenvolvimento Regional (FEDER), by Programa Operacional Factores de Competitividade (POFC) - COMPETE and by Fundação para a Ciência e Tecnologia, for the Project Scope: PEstC/EEI/UI0319/ 2015.

\section{References}

1. CGTP "Revista de Imprensa” ID 55778952, Page. 38, e ID 55778933, Page. 47, 2014.

2. Diário da República, "Recrutamento e seleção do pessoal docente", 1st series- No. 139, 21 July, 2009.

3. Ministério da Educação e Ciência, "Decreto-Lei No. 83-A/2014", no.99, May, 2014.

4. DGAE "Códigos de Agrupamentos e Escolas não agrupadas Manifestação de Referências para Necessidades Temporárias", June, 2014.

5. C. Ramos, "Teacher Evaluation in Portugal" OECD, March, 2009.

6. DGAE "Manual de instruções Mobilidade Interna" volume 01, August, 2014.

7. José Manuel Pinto Ferreira, "O Impacto do Contrato de autonomia através das perceções doa atores educativos: o caso da Escola-Piloto ES/3 João G. Zarco", 2012.

8. Ozarfaxinars, "TEIP - Territórios Educativos de Intervenção Prioritária e Matosinhos", no.22, ISSN 1645-9180, 2012.

9. DGAE "Manual de instruções Concurso Externo Extraordinário e Contratação Inicial", volume 01, May, 2014.

10. Mapa com 10 QZP's-SPLEU, “QZP-10”, http://www.sepleu.pt/concursos_13_14/MAPA_ QZP_10.pdf, Accessed December, 2014. 
11. FENPROF, "Concursos para a colocação de docentes", February, 2015.

12. UE, "Supporting the Teaching Professions for Better Learning Outcomes", November, 2012.

13. Education, Audiovisual and Culture Executive Agency, "Key Data on Teachers and School Leaders in Europe", March, ISBN 978-92-9201-412-4, 2013.

14. OECD "Country Background Report for Italy", July, 2003.

15. OECD "Country Background Report for France", July, 2003.

16. ETUCE \& EI Secretariats, "Technical Report of EFEE-ETUCE survey on Recruitment and Retention in the Education Sector", July, 2012.

17. OECD "Country Note: Germany", September, 2014.

18. Associação Nacional de Professores, "Colocação de Professores", No. 227/GP/2014, October, 2014

19. FENPROF, "Princípios defendidos pela FENPROF Revisão das normas sobre o concurso", January, 2014.

20. Sindicato Nacional dos professores Licenciados pelos Politécnicos e Universidades, "Propostas apresentadas pelo SPLIU”, 2013. 